Egyptian Poultry Science Journal

http://www.epsj.journals.ekb.eg/

ISSN: 1110-5623 (Print) - 2090-0570 (Online)

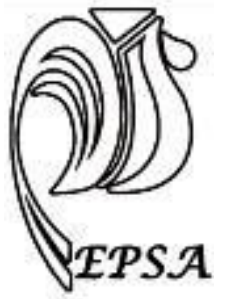

\title{
COMPARISON OF HYDRATED SODIUM CALCIUM ALUMINOSILICATE AND TURMERIC (CURCUMA LONGA) TO AMELIORATE THE ADVERSE EFFECTS OF AflATOXIN IN BROILER CHICKS
}

\author{
Reda A. Hassan ${ }^{*}$, Yahya. Z. Eid ${ }^{2}$, Ebtehal A. Hassan ${ }^{1}$, Khalil M. Attia ${ }^{1}$,
} Mohammed H. Assar ${ }^{1}$ and Hanaa A. Basuoney ${ }^{1}$

${ }^{1}$ Anim. Prod. Res. Inst., Agric. Res.h Center, Minis. of Agric., Egypt

${ }^{2}$ Dep. of Poult. Prod., Fac. of Agric., Kafrelsheikh Uni., Egypt

*Corresponding author: Reda A. Hassan ${ }^{1}$ Email: redaalihasan@yahoo.com

\begin{abstract}
The aim of this study was to determine the effectiveness of the use of curcumin-containing turmeric powder (TP) and hydrated sodium calcium aluminosilicate (HSCAS) alone or in combination to alleviated aflatoxicosis in broiler chicks. A total of 480 day-old broiler chicks were separated into 8 treatments. Each of the 8 dietary groups was divided into four replicates of 15 chicks each. The first group was fed basal diet and used as control. The other treatments (from 2 to 8 ) were fed the same basal diet and supplied with $0.5 \%$ turmeric powder (TP) including $1.48 \%$ total curcuminoids $(80 \mathrm{mg} / \mathrm{kg}(80 \mathrm{mg} / \mathrm{kg})$, Hydrated sodium calcium aluminosilicate (HSCAS) alone $(0.5 \%)$, TP $(0.5 \%)$ plus HSCAS $(0.5 \%)$, Aflatoxin B1 ( AFB1) alone in the diet (1 mg/kg of diet), AFB1 plus TP $(0.5 \%)$, AFB 1 plus HSCAS $(0.5 \%)$ and AFB1 plus TP $(0.5 \%)$ plus HSCAS $(0.5 \%$, respectively) for 35 day. The findings showed that the turmeric or HSCAS substantially addition to the AFB1 diet increased feed consumption and body weight and decreased liver weight. Supplementation of turmeric or HSCAS and turmeric with HSCAS reinforced the harmful effects of AFB1 on serum constituents. Furthermore, decreased antioxidant functions and increased serum and liver homogeneous malondialdehyde (MDA) concentrations due to AFB1. In conclusion, the combined method to the management of aflatoxicosis in broiler chicks can be considered to be the addition of HSCAS and/or turmeric.
\end{abstract}

Keywords: Aflatoxin B1, Broiler chicks, Detoxification, HSCAS, Turmeric. 
Reda A. Hassan ${ }^{1}$ et al.

\section{INTRODUCTION}

Aflatoxins (AF), a class of Aspergillus flavus and Aspergillus parasiticus fungi mycotoxins are important toxins of particular feed materials used in poultry diets (Smith et al., 1995). The highly biologically effective form of AF is AFB1, which causes poor poultry outcomes, hepatic lesions and immunosuppression (Ledoux et al., 1998). The negative effects of AFB1 include damage to cells, free radical release and lipid peroxidation (Surai, 2002). To enhance the toxic effects of AFB1 on poultry diets, adsorbents were used and some aluminosilicate binders showed beneficial effects (Ledoux et al., 1998). Since lipid peroxidation plays a major role in AF toxicity, antioxidants can have a protective impact (Galvano et al., 2001). Inhibitory action of plant compounds such as coumarins, flavonoids and curcuminoids on the biotransformation of AF to their active epoxy derivatives (Lee et al., 2001). It is understood that Turmeric (Curcuma longa), a medicinal plant native to the Asian subcontinent, has antimicrobial and antioxidant properties. In Indian curries and other cuisines, the powder of dried turmeric roots and rhizomes is used as one of the spices. The yellowish pigments present in turmeric powder, the curcuminoids, have shown protective effects against AFB1 (Sonietal., 1997). The mixed use of antioxidants and adsorbents is the biggest recent dietary initiative to avoid mycotoxicosis in poultry (Surai, 2002). The aim of this study was to determine the effectiveness of the use of curcumincontaining turmeric powder (TP) and hydrated sodium calcium aluminosilicate (HSCAS) alone or in combination to alleviated aflatoxicosis in broiler chicks, and to demonstrate that the use of turmeric powder and HSCAS in poultry diets does not adversely affect the effectiveness of chicks.

\section{MATERIALS AND METHODS}

\section{Aflatoxin B1 production:}

Aflatoxin given by the standard toxigenic strain Aspergillus parasiticus, obtained from Institute of Animal Health, Dokki, Cairo, Egypt. Aflatoxin was produced on maize using the Shotwell (Shotwell et al., 1966) process. Productive aflatoxin was assessed by competitive ELISA kit (Romer Co., Denver, CO).

Hydrated Sodium Calcium Aluminosilicate (HSCAS) is a feed additive, adsorbent, anticaking and toxin binder that was obtained from Trouw Nutrition International and mixed with the ration at a rate of $5 \mathrm{~g} / \mathrm{kg}$ (0.5\%). Hydrated sodium calcium aluminosilicate clay (HSCAS) is a chemical compound that contains Silicon oxide $(64.7 \%)$, aluminum oxide (15.5\%), oxides of iron, magnesium, calcium, sodium, potassium $(8.9 \%)$ and moisture $(10.9 \%)$.

Rhizomes of turmeric [Curcuma longa $L$. (Zingiberaceae)] A phytobiotic feed additive turmeric powder (Curcuma longa) was added in a dose of total curcuminoid content (curcumin, bisdemethoxycurcumin and demethoxy curcumin) $80 \mathrm{mg} / \mathrm{kg}$ of the ration.

\section{Diet:}

The chicks were submitted to conventional broiler chicken management and housed in floor pens in an environmentally controlled broiler house with litter floors. They were fed a commercial starter-grower diet (based on corn and soybean meal) up to 21 days of age and then switched to finisher diet from 22 to 35day (Table 1). The ration has been designed to meet or exceed chickens' nutritional requirements, as suggested by the NRC (1994). Birds were allowed to feed and water ad libitum. Before feeding experimental chickens, the basal diet was checked for possible residual mycotoxins 
Aflatoxin B1, Broiler chicks, Detoxification, HSCAS, Turmeric.

such as aflatoxins, ochratoxins, zeralenone and fuminsin (Rottinghaus et al., 1982), but no detectable levels of mycotoxins were present.

\section{Detection of aflatoxin B1 in the Diet:}

According to Schuller and Egmond (1981), a statistically valid sample was drawn from the lot of ration during the analysis to test aflatoxin B1 by immunoaffinity chromatography, and positive samples were calculated quantitatively by fluorometry process according to AOAC (2005).

\section{Experimental chicks:}

Broiler chicks that were used in this study were bought from a commercial hatchery. The birds had been housed in properly washed and disinfected pens. During the experimental duration (35 days) the birds were kept on a 24-hour continuous light cycle. During the brooding time, the temperature was kept up to the required. At the age of 7 days, chicks were vaccinated against Newcastle Disease (ND) and infectious bronchitis disease using intraocular Hitchner B1+H120 vaccine, and at the age of 9 day, using inactivated H5N2 vaccine by intramuscular. Vaccination against infectious bursal disease and ND was performed at 15 days of age using $228 \mathrm{E}$ strain and La Sota vaccines, respectively by intraocular route.

\section{Experimental design:}

A total of 480, day-old broiler chicks were distributed into eight dietary treatments. Four pen replicates of 15 chicks each were allocated to each of 8treatments.The first treatment was fed basal diet and used as control. The other treatments (from 2 to 8 ) were fed the same basal diet and supplied with $0.5 \%$ turmeric powder (TP) including $1.48 \%$ total curcuminoids $(80 \mathrm{mg} / \mathrm{kg}(80$ $\mathrm{mg} / \mathrm{kg})$, HSCAS alone $(0.5 \%)$, TP $(0.5 \%)$ plus HSCAS $(0.5 \%)$, AFB1 alone in the diet $(1 \mathrm{mg} / \mathrm{kg}$ of diet) for $35 \mathrm{~d}$, AFB1 plus TP $(0.5 \%)$, AFB1 plus HSCAS $(0.5 \%)$ and
AFB1 plus TP (0.5\%) plus HSCAS $(0.5 \%$, respectively).

\section{Growth parameters:}

On day 35 , birds were weighed by pen and reported total feed consumption for each pen. Average feed intake and final body weight were balanced for mortality while the feed conversion was determined for each pen.

\section{Serum biochemical variables:}

Blood was collected at $35 \mathrm{~d}$ of age from 8 birds in each treatment in non-heparinised tubes by brachial vein puncture. Serum was obtained from these samples and analyzed for serum albumin, total protein, uric acid, creatinine and the activities of alanine amino transferase (ALT) and aspartate aminotransferase (AST) in blood serum were analyzed by using commercial kits from Diamond Diagnostics Company, Egypt. Serum Globulin (G) levels were calculated as differences between albumin and total proteins.

Serum and liver antioxidant enzyme activities assays:

The liver samples (the tip of the left lobe) were collected and washed away in ice-cold physiological saline within $1 \mathrm{~h}$ postmortem. Approximately $0.5 \mathrm{~g}$ of liver was homogenized In $4.5 \mathrm{~mL}$ of ice-cold physiological saline. The homogeneous was then centrifuged for $10 \mathrm{~min}$ at $1200 \mathrm{~g}$ at $4^{\circ}$ C. For the following study, the supernatant was collected and deposited in a freezer at $-70^{\circ} \mathrm{C}$. The activities of GSH-Px and SOD, and MDA content in serum and hepatic supernatants were analyzed using commercial kits (Nanjing Jiancheng Bioengineering Institute, Nanjing, China) as per the kit guidelines.

\section{Immunological parameters:}

Birds' humoral immune response to NCDV post-vaccination has been adjudicated by estimating titer haemaggutination inhibition 
Reda A. Hassan ${ }^{1}$ et al.

(HI) at weekly intervals as suggested by OIE (2000).

Detection of aflatoxin residues: liver was analyzed for quantification of aflatoxin residues using the method according to (AOAC, 2000).

\section{Statistical analysis:}

Results from all response variables have been subjected to one-way variance analysis (SAS, 2000). Using Duncan's Multiple Range Test (Duncan, 1955), mean of variables with a significant F-test $(\mathrm{P} \leq 0.05)$ were compared.

\section{RESULTS AND DISCUSSION Performance of chicks:}

Chicks fed TP or HSCAS alone had the same feed consumption, final body weight and FCR as control chicks (Table 2). When compared with control, the chicks fed $1 \mathrm{mg} /$ $\mathrm{kg}$ AFB1 had a significantly lower final body weight, body weight gain and feed consumption. Also, feeding the contaminated diet with AF alone resulted in a significant increase in the FCR. These results are consistent with previous performance-reducing research on the effects of aflatoxin B1 (Shi et al., 2006 and Denli et al., 2009). As described by Verma et al. (2002), growth depression following aflatoxin feeding may be due to decreased protein synthesis; increased lipid excretion in droppings, decreased nutrient absorption and decreased pancreatic digestive enzyme production by Osborne and Hamilton (1981); and decreased appetite by Sharline et al. (1980); Hasan et al. (2000) indicated that aflatoxin toxicity was characterized by a diminution in body weight gain as aflatoxins intervene with normal metabolic processes by inhibiting the protein synthesis and enzyme system involved in the metabolism of carbohydrates and the release of energy. Nelson et al. (1982) addressed another point of view, arguing that aflatoxin restricts the ability of the bird to digest dry matter and amino acids and to use energy from the aflatoxin-polluted ration. Feed intake in broilers fed with aflatoxin B1 has decreased significantly $(\mathrm{p}<0.05)$, suggesting decreased appetite during aflatoxicosis as a protective mechanism (Rauber et al., 2007) or impaired liver metabolism due to liver damage (Johri and Majmudar 1990).

Addition of $0.5 \%$ HSCAS, turmeric powder or a combination of their significantly increased body weight and feed intake at 35 days as compared with the aflatoxicated group. There was an improvement in feed conversion ratio for treatments fed AF-diet supplemented with HSCAS, turmeric powder or their combination as compared with the AF-diet alone group.

Adding $0.5 \%$ HSCAS to the AFB1 diet enhanced the growth and feed consumption was similar to control chicks' performance. The addition of turmeric powder to the diet, including AFB1 and HSCAS together, did not lead to an additional increase in chick performance compared to chicks fed the diet, including AFB1 and HSCAS together, indicating that the adsorbent (HSCAS) was more effective in reducing the adverse effects of AFB1 than the antioxidant (turmeric powder).

\section{Serum chemical parameters:}

Biochemical parameter analysis has revealed significant differences between the groups in AST, ALT, total protein, albumin, creatinine and uric acid (Table 3). AFB1 caused a decrease in serum $\mathrm{T}$. protein, albumin and globulin were significantly lower compared to the control group. Also, feeding the contaminated diet with AF caused a significant increase in serum AST, ALT activities, uric acid and creatinine at 35 days of age $(\mathrm{P}<0.05)$.

Chicks that fed AFB1 (1.0 mg / kg) contributed to substantially decreased levels of serum total protein, globulin and albumin (Table 3). The decreased albumin and total 


\section{Aflatoxin B1, Broiler chicks, Detoxification, HSCAS, Turmeric.}

protein levels are indicative of the toxic effect of aflatoxin B1 on hepatic and renal tissue, in line with previous literature documenting aflatoxicosis (TejadaCastaneda et al., 2008). The decrease in total serum protein in the aflatoxin-fed group may be associated with impairment of the transport of amino acids and mRNA transcription by inhibiting DNA (Kubena et al., 1993a). In chicks fed with aflatoxin B1, serum creatinine and uric acid were significantly elevated $(\mathrm{p}<0.05)$. Increased levels of creatinine and uric acid, combined with the kidney enlargement observed, may suggest some of the renal tissue damage caused by aflatoxin B1. Data reports from Denli et al. (2005) and Bintvihok and Kositcharoenkulul (2006) are consistent with the present study. The addition of HSCAS and turmeric powder $(\mathrm{p}<0.05)$ was significantly effective in protecting against aflatoxin B1 by preventing its toxic effect, as reflected by improving changes in serum biochemical parameters (increasing serum total protein, albumin, globulin levels and decreasing serum creatinine and uric acid). Tumeric powder provides protection against antioxidants and HSCAS decreases the absorption of B1 aflatoxin. Kubena et al. (1990a), Ledoux et al. (1998) and Gowda et al. (2008) noted that the reduction in these aflatoxin-sensitive serum proteins was prevented by adding certain additives to the aflatoxin B1 diet. The adverse effect of aflatoxin B1 on serum chemistry was reversed by the addition of cumin (Nigella sativa) and clove (Syzygiumaromaticum) plant extracts to a rat diet containing aflatoxin B1 (Abdel-Wahhab and Aly, 2005).

Liver functions such as (AST and ALT) significantly $(\mathrm{p}<0.05)$ showed the lowest group values that were handled with both HSCAS and turmeric powder compared to chicks fed only with aflatoxin B1, while these values were relatively low in chicks treated with either HSCAS or turmeric powder. A rise in the liver enzyme profile in the aflatoxicated ration most likely represents liver tissue damage, alternating the integrity of the hepatocyte membrane with enzyme leakage into the blood (Duncan and Prasse, 1986). The findings herein are consistent with the results of Aravind et al. (2003) and Denli et al. (2009), which documented an increase in AST and ALT behaviors following feeding with various doses of diet contaminated with aflatoxin. Manegar et al. (2010) were unable to report any major alteration in the liver enzyme profile for feeding birds with aflatoxin. The variations in the enzyme profile mean, as told by multiple researchers, that AST and ALT concentrations do not reflect the degree of liver damage or may be a true predictor of aflatoxicosis. Abdel-Wahhab et al. (1998) successfully examined the control of liver enzymes after treatment of the aflatoxincontaminated diet with HSCAS, while Emadi and Kermanshahi (2007) fed turmeric powder $(0.25,0.5$ and 0.75 percent respectively) from hatch to 49 days for broiler chicks and concluded that turmeric could have positive effects on liver enzymes by decreasing alanine aminotransferase and alkalininase. The decrease in serum chemistry data due to HSCAS and the addition of turmeric powder to the aflatoxin B1diet is accurate with the magnitude of lesions due to liver antioxidant status.

\section{Liver antioxidant status:}

The amount of lipid peroxide (MDA) in serum and liver homogenate was increased $(\mathrm{p}<0.05)$ in the chicks fed AFB1 relative to the control diet. Turmeric powder or HSCAS supplementation or their combination diets decreased the content of serum and hepatic MDA (Table 4). SOD and GSH-Px activity in the group fed the diet added to turmeric powder was higher 


\section{Reda A. Hassan ${ }^{1}$ et al.}

compared to controls and group fed the AFB1 diet added with turmeric powder or HSCAS. In serum and liver homogenates the total antioxidant concentration was significantly comparable but numerically greater in the chicks fed the mixture of turmeric powder and AFB1-diet. The antioxidant data generally indicate that in order to counteract the oxidative damage caused by AFB1, the introduction of turmeric powder along with AFB1 enabled the antioxidant mechanism in the liver. In the groups supplied with a combination of HSCAS and AFB1, the lower level of MDA showed minimal to no cell damage to the liver because adequate AFB1 was adsorbed into the HSCAS to decrease the levels of gut AFB1 to or below the maximum tolerable level for birds of this age.

Aflatoxins produce intracellular reactive oxygen species (ROS) such as superoxide anion, hydrogen peroxide, and hydroxyl radicals during their metabolic processing in the liver. The principal antioxidant enzymes which scavenge ROS in cells are SOD and GSH-Px. Oxidative stress occurs when the levels of ROS exceed the resistance potential of the cellular antioxidant defence mechanism. As the end product of lipid peroxidation after the incidence of oxidative stress, MDA concentration in blood and tissues grows. Overall, our observations on reduced serum SOD and GSH-Px activity and elevated serum and liver MDA concentrations in AFB1 diet birds are consistent with previous reports of broiler exposure to aflatoxin (Yang, et al., 2012). These data suggest that aflatoxincontaminated dietary feeding induced oxidative harm and lipid peroxidation in chicks, which could be the main cause of liver tissue damage and serum biochemical alterations. Aflatoxin B1 is known to cause lipid peroxidation in the liver and is a strong carcinogen that forms DNA adducts and causes cellular oxidative damage (Shen et al., 1994). A decrease in the activity of SOD, catalase, glutathione peroxidase and reductase was correlated with an increase in the amount of MDA in the liver due to feeding of AFB1 to rats (Rastogi et al., 2001), and further addition of Picrorhiza kurroa root extracts and Silybum marianum seeds improved the control levels of the effects of AFB1 and reversed peroxide and antioxidant enzymes. Rosamarinic acid, an aphenolic compound found in Boraginaceae (sage, basil, mint) plants, decreased the production of free radical oxygen and the apoptosis of human hepatoma cells induced by AFB1 (Renzulli et al., 2004). The carbonyl functional group of curcuminoids of turmeric was responsible for its antimutagenic and anticarcinogenic action (Chun et al., 1999). Moreover, curcumin has a strong inhibitory effect on superoxide anion production (Iqbal et al., 2003) and on the biotransformation of AFB1 into aflatoxicol in the liver (Lee et al., 2001). Turmeric supplementation is known to minimise AFB1-DNA adduct formation by modulating the role of cytochrome P450 (Soni et al., 1997). The above results define the mode of action of curcumin as an antioxidant, and the results of this study suggest that it would be appropriate to add curcumin at rates higher than the $80 \mathrm{mg} / \mathrm{kg}$ used in the current study to achieve optimum protection against the diet of $1.0 \mathrm{mg}$ AFB1/kg.

\section{Liver weight}

When compared to control chicks, relative liver weight was increased in chicks fed the diet containing AFB1 alone. The liver is considered to be the target organ of aflatoxin $\mathrm{B} 1$ because it is the organ in which most aflatoxins are bioactivated in the reactive 8 , 9-epoxide form known to bind DNA and proteins, damage the structure of the liver and increase the weight of the liver (Miazzo 


\section{Aflatoxin B1, Broiler chicks, Detoxification, HSCAS, Turmeric.}

et al., 2005; Bailey et al., 2006 and Pasha et al., 2007). The increase in liver weight due to damaged fat metabolism may be credited to enlarged lipid deposits in the liver (Hsieh, 1979). The hepatic lipidosis is chiefly arbitrated by inhibition of phospholipids production and cholesterol. This in-turn impacts lipid transfer from the liver (Manegar et al., 2010).

Supplementation of $0.5 \%$ turmeric powder, HSCAS, or their combination significantly reduced the severity of aflatoxicosis on liver weight against 1ppm AFB1.

Addition of HSCAS to the AFB1 diet was above efficient than turmeric powder in diminishing the adverse results of AFB1 in the liver. Different results were obtained by Sehu et al. (2007) and Zhao et al. (2010) who decided that HSCAS could significantly and fully improve the growth-depressive effect of aflatoxin B1 at a concentration of 5 percent as silica binders have been shown to bind toxins in the digestive tract, rendering them unavailable for intestinal absorption and allowing mycotoxin to pass through the animal harmlessly. The $\beta$-carbonyl portion of the aflatoxin molecule binds the HSCAS aluminium ions to the uncoordinated edge site, rendering the aflatoxin molecule unavailable for adsorption (Sarr et al., 1990). Mabbett (2005) found that the addition of binders at levels above 5 percent could have diluted the formulated feed's nutritional value and ultimately decreased the performance of birds. On the other hand, the growth-promoting effect of turmeric (Curcuma longa) on aflatoxin B1 was studied by Yarru et al. (2009b) and Rangsaz and Ahangaran (2011), as they showed that supplementing ethanolic turmeric extract in a 3 ppm aflatoxin diet would significantly boost performance indices compared to the aflatoxin alone community. Curcumin, the main antioxidant ingredient in turmeric, is known to inhibit the biotransformation of aflatoxin B1 into aflatoxicol in the liver (Lee et al., 2001) and is also responsible for its anti-mutagenic and anticancer function (Chun et al., 1999). Emadi and Kermanshahi (2007) fed turmeric powder (0.25, 0.5 and 0.75 percent respectively) to broiler chicks from hatch to 49 days of age and concluded that turmeric could have some positive effects on the activity of liver enzymes that suggest healthier liver status in birds directly or indirectly. Gowda et al. (2008) were partly in agreement with our study, as they noticed that supplementing chicks with turmeric powder by 5 percent to the aflatoxin B1 contaminated diet partially increased feed consumption, body weight gain and chick feed conversion, suggesting turmeric powder as antioxidant safety. Compared to either turmeric powder or HSCAS alone the supplementation of the AFB1 diet with a combination of both turmeric powder and HSCAS resulted in no additional benefits, suggesting that the concentration of curcumnoids (80 mg / kg) given by the amount of turmeric powder ( 0.5 percent) used in their study was too small to exert a more potent antioxidant action.

\section{Aflatoxin residues:}

Results in table (4) showed that the administration of aflatoxin in broilers resulted in the accumulation of AFB1 in the liver, with the highest level of AFB1 in the aflatoxicated community, which results in agreement with that obtained in the liver (Bintvihok and Kositchaenkal 2006). The lowest amount of AFB 1 residues was shown by the supplementation of HSCAS or turmeric powder to feed and their combination with aflatoxic diets. These findings are consistent with Hassan et al. (2009). Results in the present study showed that compared to turmeric powder, the addition of HSCAS to broiler diets as a decontamination tool for selectively sorbing aflatoxin during the digestive process was highly effective was high effective compared to turmeric powder.

\section{Humoral immune response of birds against NCDV:}

With regard to the results of chickens' humoral immune response to ND vaccination using the HI test, Table 5 shows that the antibody titers of the community of chickens fed on a diet infected with aflatoxin B1 alone were significantly $(p<0.05)$ the lowest at all intervals compared to the control diet. Although the introduction into feed of either HSCAS or turmeric powder and their combination with aflatoxin B1 contaminated rations $(\mathrm{p}<0.05)$ significantly improved the chickens' immune response. This finding indicates that the immune system of 


\section{Reda A. Hassan ${ }^{1}$ et al.}

birds was substantially inhibited by the ND vaccine aflatoxin, which resulted in a reduction of the ND titer. The decreased immune response observed in the present study may account for decreased protein and globulin synthesis (Table 3), impaired antigen processing during ochratoxicosis in poultry due to impaired phagocytosis as previously reported (Kalorey, 1993). Decreased mean geometric antibody titers against ND were shown by Tessari et al. (2006), who documented broilers fed aflatoxin B1treated diets. Mussaddeq et al. (2000) have shown that aflatoxin reduces disease tolerance and induces immunity in livestock by interfering with vaccines. Manegar et al. (2010) reported that as evident from falling ELISA titers, aflatoxin induces bursal regression and suppresses primary immune response to ND and Gumboro disease. Following the introduction of binders such as HSCAS in this study, enhancing the humoral immune response is consistent with Ibrahim et al. (2000), who found that adding sodium bentonite binder was significantly effective in reducing the negative effect of aflatoxin on the percentage and mean of phagocytosis and HI-titer in chicks vaccinated with ND. In addition, Sehu et al. (2007) investigated the effect of HSCAS on the humoral immune response of quails fed on aflatoxin B1 contaminated rations, and found a decrease in the ND vaccine antibody titer caused by aflatoxin. By applying polyherbal preparation to chicks, there was partial protection against mycotoxin triggered by immune-toxicity. As noted in current research, this could be due to the defence of immune organs against the histotoxic impact of mycotoxins. In addition, due to the addition of Curcuma longa and 5 percent artichoke extract during experimental aflatoxicosis and ochratoxicosis, Kurkure et al. (2000) and Stoev et al. (2000) have documented improved chick immune response.

Evidence from this study showed that aflatoxin B1 caused substantial adverse toxic side effects on broiler chickens; clinically, this damage (signs and lesions), parameters of zootechnical performance relative liver weight, immune response, and serum biochemical variables were evident. The toxicity resulting from aflatoxin B1 was significantly reduced by the separate or concomitant dietary application of HSCAS or turmeric powder. It can therefore be concluded that in broiler chickens, HSCAS and/or turmeric powder can be considered an integrated approach for controlling aflatoxicosis. It is important to remember, however that mycotoxins are complex organic compounds and each of them has different functional groups; hence the binding capacity of an adsorbent depends on its chemical and physical properties and its relation to the physical structure of the target mycotoxins. Therefore the physicochemical differences between the adsorbents used in the studies described above can explain their greater or lesser efficacy.

\section{CONCLUSIONS}

This study concludes that supplementing a diet containing AFB1 $(1.0 \mathrm{mg} / \mathrm{kg})$ with a turmeric powder containing $80 \mathrm{mg} / \mathrm{kg}$ of curcumin improved the antioxidant status and partially protected against the adverse effects of AFB1, suggesting that higher levels of curcumin may be needed for optimum efficacy. The addition of HSCAS (0.5 percent) to the diet including AFB1 (1.0 $\mathrm{mg} / \mathrm{kg}$ ) protected the toxic effects of AFB1 approximately absolutely. The combined inclusion of TP (0.5 percent) and HSCAS ( 0.5 percent $)$ in the AFB1 diet $(1.0 \mathrm{mg} / \mathrm{kg})$ did not contribute to any further change in the toxic effects of AFB1 relative to the addition of TP or HSCAS alone. 
Table (1): Composition and calculated analysis of starter and finisher diets.

\begin{tabular}{|l|c|c|}
\hline Ingredients & Starter-grower (1-21d) & Finisher (22-35d) \\
\hline Yellow corn & 54.40 & 62.00 \\
Soybean meal, 44\% & 27.00 & 24.05 \\
Corn Gluten meal, 60\% & 10.00 & 6.19 \\
Soy bean oil & 4.55 & 4.00 \\
Limestone & 1.10 & 1.00 \\
Di-calcium phosphate & 2.20 & 2.05 \\
Vit\&min. premix* & 0.30 & 0.30 \\
DL-Methionine & 0.05 & 0.01 \\
L-lysine (HCl) & 0.15 & 0.15 \\
Na Cl & 0.25 & 0.25 \\
Total & 100 & 100 \\
\hline Calculated analysis: ** & \multicolumn{2}{|c|}{} \\
\hline CP, \% & 23.03 & 20.02 \\
ME (Kcal/kg) & 3204 & 3201 \\
Calcium, \% & 1.05 & 0.97 \\
Available phosphorus, \% & 0.45 & 0.42 \\
Lysine, \% & 1.14 & 1.03 \\
Methionine, \% & 0.52 & 0.41 \\
TSAA, \% & 0.90 & 0.73 \\
\hline
\end{tabular}

*Each 3kg contain: Vit A 12000000IU, Vit D3 2000000 IU, Vit E 10g, Vit K3 2g,Vit B1 1g, Vit B2 5g, Vit B6 1.5g, Vit B12 10mg, Nicotinic acid 30g, Pantothenic acid 10g, Folic acid 1g, Biotin 50mg, Choline chloride 250g, Iron 30g, Copper 10g, Zinc 50g, Manganese 60g, Iodine 1g, Selenium 0.1g, Cobalt $0.1 \mathrm{~g}$ and carrier (CaCo3) to $3 \mathrm{~kg}$. **According to tables of NRC (1994). 
Reda A. Hassan ${ }^{1}$ et al.

Table (2): Body weight gain, feed intake and feed conversion ratio of chicks fed diets containing HSCAS, TP and AFB1.

\begin{tabular}{|l|c|c|c|c|c|}
\hline \multicolumn{1}{|c|}{ Treatments } & $\begin{array}{c}\text { Initial } \\
\text { body } \\
\text { weight } \\
\text {, }\end{array}$ & $\begin{array}{c}\text { Final } \\
\text { body } \\
\text { weight, } \\
\boldsymbol{g}\end{array}$ & $\begin{array}{c}\text { Body } \\
\text { weight } \\
\text { gain, } \\
\text { g/chick }\end{array}$ & $\begin{array}{c}\text { Total } \\
\text { feed } \\
\text { intake } \\
\text { (g/chick) }\end{array}$ & $\begin{array}{c}\text { Feed } \\
\text { conversion } \\
\text { ratio }(\boldsymbol{g} \\
\text { feed:g } \\
\text { gain) }\end{array}$ \\
\hline Basal diet (Control) & 45.08 & $1771.66^{\mathrm{bc}}$ & $1726.58^{\mathrm{bc}}$ & $3063.66^{\mathrm{a}}$ & $1.774^{\mathrm{bc}}$ \\
Control+0.5\% TP & 45.11 & $1796.66^{\mathrm{a}}$ & $1751.55^{\mathrm{a}}$ & $3061.33^{\mathrm{a}}$ & $1.747^{\mathrm{d}}$ \\
Control +0.5\% HSCAS & 45.16 & $1786.66^{\mathrm{ab}}$ & $1741.50^{\mathrm{ab}}$ & $3062.66^{\mathrm{a}}$ & $1.758^{\mathrm{cd}}$ \\
Control+0.5\% TP + 0.5\% HSSCAS & 45.23 & $1790.00^{\mathrm{ab}}$ & $1744.76^{\mathrm{ab}}$ & $3076.66^{\mathrm{a}}$ & $1.763^{\mathrm{cd}}$ \\
Control+1ppmAFB1/kgdiet(AFB1-diet) & 45.30 & $1603.33^{\mathrm{e}}$ & $1558.03^{\mathrm{e}}$ & $2973.33^{\mathrm{c}}$ & $1.908^{\mathrm{a}}$ \\
AFB1-diet + 0.5\% TP & 45.30 & $1720.00^{\mathrm{d}}$ & $1674.70^{\mathrm{d}}$ & $3000.00^{\mathrm{b}}$ & $1.791^{\mathrm{b}}$ \\
AFB1-diet + 0.5\% HSCAS & 45.16 & $1770.00^{\mathrm{bc}}$ & $1724.83^{\mathrm{bc}}$ & $3015.00^{\mathrm{b}}$ & $1.748^{\mathrm{d}}$ \\
AFB1-diet+0.5\%HSCAS+0.5\%TP & 45.10 & $1763.33^{\mathrm{c}}$ & $1718.23^{\mathrm{c}}$ & $3018.33^{\mathrm{b}}$ & $1.756^{\mathrm{cd}}$ \\
SEM & 0.0294 & 12.599 & 12.610 & 7.467 & 0.0105 \\
p-value & 0.411 & 0.0001 & 0.0001 & 0.0001 & 0.0001 \\
\hline
\end{tabular}

${ }^{\mathrm{a}-\mathrm{e}}$ Means with different superscripts in a column differ significantly $(\mathrm{P}<0.05) . * \mathrm{SEM}=$ Standard Error of the mean; $\mathrm{AFB} 1=$ aflatoxin $\mathrm{B} 1 ; \mathrm{TP}=$ turmeric powder; HSCAS $=$ hydrated sodium calcium aluminosilicate.

Table (3): Serum biochemical variables of chicks fed diets containing HSCAS, TP and AFB1

\begin{tabular}{|c|c|c|c|c|c|c|c|}
\hline Treatments & $\begin{array}{c}\text { T.protein } \\
\text {, g/dl }\end{array}$ & $\begin{array}{c}\text { Albumi } \\
n, g / d l\end{array}$ & $\begin{array}{c}\text { Globuli } \\
n, \text { g/dl }\end{array}$ & $\begin{array}{l}A S T, \\
I U / L\end{array}$ & $\begin{array}{l}A L T, \\
I U / L\end{array}$ & $\begin{array}{c}\text { Creatin } \\
\text { ine, } \\
\text { mg/dl }\end{array}$ & $\begin{array}{l}\text { Uric } \\
\text { acid, } \\
\text { mg/dl }\end{array}$ \\
\hline Basal diet (Control) & $3.33^{\mathrm{a}}$ & $1.61^{\mathrm{a}}$ & $1.72^{\mathrm{b}}$ & $147.98^{\mathrm{e}}$ & $68.93^{\mathrm{d}}$ & $0.436^{\mathrm{c}}$ & $6.10^{\mathrm{d}}$ \\
\hline Control+0.5\% TP & $3.30^{\mathrm{a}}$ & $1.28^{\mathrm{b}}$ & $2.02^{\mathrm{a}}$ & $144.00^{\mathrm{e}}$ & $68.53^{\mathrm{d}}$ & $0.436^{\mathrm{c}}$ & $6.00^{\mathrm{d}}$ \\
\hline Control $+0.5 \%$ HSCAS & $3.25^{\mathrm{a}}$ & $1.30^{\mathrm{b}}$ & $1.94^{\mathrm{a}}$ & $143.16^{\mathrm{e}}$ & $68.26^{\mathrm{d}}$ & $0.456^{\mathrm{c}}$ & $5.90^{\mathrm{d}}$ \\
\hline Control $+0.5 \% \mathrm{TP}+0.5 \% \mathrm{HSCAS}$ & $3.26^{\mathrm{a}}$ & $1.29^{\mathrm{b}}$ & $1.97^{\mathrm{a}}$ & $144.43^{\mathrm{e}}$ & $68.16^{\mathrm{d}}$ & $0.483^{\mathrm{c}}$ & $5.90^{\mathrm{d}}$ \\
\hline (AFB1-diet) & $1.79^{\mathrm{c}}$ & $0.75^{\mathrm{c}}$ & $1.03^{\mathrm{d}}$ & $308.73^{\mathrm{a}}$ & $119.3^{\mathrm{a}}$ & $1.300^{\mathrm{a}}$ & $9.03^{\mathrm{a}}$ \\
\hline AFB1-diet $+0.5 \%$ TP & $3.06^{\mathrm{b}}$ & $1.59^{\mathrm{a}}$ & $1.47^{\mathrm{c}}$ & $199.83^{\mathrm{d}}$ & $75.40^{\mathrm{b}}$ & $0.596^{\mathrm{b}}$ & $7.03^{\mathrm{b}}$ \\
\hline AFB $1-$ diet $+0.5 \%$ HSCAS & $2.93^{\mathrm{b}}$ & $1.31^{\mathrm{b}}$ & $1.61^{\mathrm{bc}}$ & $236.66^{\mathrm{b}}$ & $71.63^{\mathrm{c}}$ & $0.583^{\mathrm{b}}$ & $6.60^{\mathrm{c}}$ \\
\hline AFB1-diet+0.5\%HSCAS+0.5\% TP & $3.03^{\mathrm{b}}$ & $1.43^{\mathrm{b}}$ & $1.60^{\mathrm{bc}}$ & $215.16^{\mathrm{c}}$ & $70.50^{\mathrm{cd}}$ & $0.546^{\mathrm{b}}$ & $6.26^{\text {cd }}$ \\
\hline SEM & 0.099 & 0.053 & 0.065 & 11.708 & 3.429 & 0.030 & 0.210 \\
\hline $\mathrm{p}$-value & 0.0001 & 0.0001 & 0.0001 & 0.0001 & 0.0001 & 0.0001 & 0.0001 \\
\hline
\end{tabular}

${ }^{\mathrm{a}-\mathrm{e}}$ Means with different superscripts in a column differ significantly $(\mathrm{P}<0.05)$. ${ }^{*} \mathrm{SEM}=$ Standard Error of the mean; AFB1 = aflatoxin B1; TP = turmeric powder; HSCAS $=$ hydrated sodium calcium aluminosilicate. AST: Aspartate aminotransferase; ALT: Alanine aminotransferase 
Aflatoxin B1, Broiler chicks, Detoxification, HSCAS, Turmeric.

Table (4): Serum, liver antioxidant status and liver AFB1 residues of chicks fed diets containing HSCAS, TP andAFB1.

\begin{tabular}{|c|c|c|c|c|c|c|c|c|}
\hline \multirow[b]{2}{*}{ Treatments } & \multicolumn{3}{|c|}{ Serum } & \multicolumn{3}{|c|}{ Hepatic } & \multirow{2}{*}{$\begin{array}{c}\text { Liver } \\
\text { weight, } \\
\%\end{array}$} & \multirow{2}{*}{$\begin{array}{c}\text { Liver } \\
\text { AFB1 } \\
\text { residues } \\
\text { (ng/g) }\end{array}$} \\
\hline & $\begin{array}{c}\text { SOD } \\
\text { (U/mg } \\
\text { prot) }\end{array}$ & $\begin{array}{c}\text { GSH-Px } \\
\text { (U/mg } \\
\text { prot) }\end{array}$ & $\begin{array}{c}\text { MDA } \\
\text { (nmol/ } \\
\text { mgprot) }\end{array}$ & $\begin{array}{c}\text { SOD } \\
\text { (U/mg } \\
\text { prot) }\end{array}$ & $\begin{array}{c}\text { GSH- } \\
\text { Px } \\
\text { (U/mg } \\
\text { prot) }\end{array}$ & $\begin{array}{c}\text { MDA } \\
\text { (nmol/ } \\
\text { mgprot) }\end{array}$ & & \\
\hline Basal diet (Control) & $119.16^{\mathrm{a}}$ & $481.33^{\mathrm{a}}$ & $16.33^{\mathrm{c}}$ & $286.33^{\mathrm{ab}}$ & $71.43^{\mathrm{a}}$ & $0.217^{\mathrm{C}}$ & $2.69^{\mathrm{e}}$ & N.D \\
\hline Control + $0.5 \% \mathrm{TP}$ & $119.66^{\mathrm{a}}$ & $489.16 \mathrm{a}$ & $15.43^{\mathrm{c}}$ & $289.66^{\mathrm{a}}$ & $72.26^{\mathrm{a}}$ & $0.220^{\mathrm{c}}$ & $2.64^{\mathrm{e}}$ & N.D \\
\hline Control $+0.5 \%$ HSCAS & $117.00^{\mathrm{b}}$ & $482.33^{\mathrm{a}}$ & $16.50^{\mathrm{c}}$ & $284.66^{\mathrm{bc}}$ & $72.16^{\mathrm{a}}$ & $0.255^{\mathrm{c}}$ & $2.60^{\mathrm{e}}$ & N.D \\
\hline $\begin{array}{l}\text { Control }+0.5 \% \mathrm{TP}+0.5 \\
\% \text { HSCAS }\end{array}$ & $117.66^{\mathrm{ab}}$ & $484.33^{\mathrm{a}}$ & $16.56^{\mathrm{c}}$ & $290.00^{\mathrm{a}}$ & $72.00^{\mathrm{a}}$ & $0.231^{\mathrm{c}}$ & $2.72 \mathrm{~d}^{\mathrm{e}}$ & N.D \\
\hline $\begin{array}{l}\text { 1ppm AFB1/kg diet } \\
\text { (AFB1-diet) }\end{array}$ & $101.20^{\mathrm{e}}$ & $408.33^{\mathrm{d}}$ & $28.06^{\mathrm{a}}$ & $250.66^{\mathrm{e}}$ & $54.40^{\mathrm{d}}$ & $0.525^{\mathrm{a}}$ & $3.80^{\mathrm{a}}$ & $0.85^{\mathrm{a}}$ \\
\hline AFB1-diet + 0.5\% TP & $114.00^{\mathrm{c}}$ & $473.00^{\mathrm{b}}$ & $20.66^{\mathrm{b}}$ & $278.66^{\mathrm{d}}$ & $67.50^{\mathrm{b}}$ & $0.340^{\mathrm{b}}$ & $3.00^{\mathrm{b}}$ & $0.21^{\mathrm{b}}$ \\
\hline AFB1-diet+0.5\% HSCAS & $111.00^{\mathrm{d}}$ & $459.33^{c}$ & $20.83^{\mathrm{b}}$ & $276.33^{\mathrm{d}}$ & $66.16^{\mathrm{bc}}$ & $0.375^{\mathrm{b}}$ & $2.83^{\mathrm{b}}$ & $0.20^{\mathrm{b}}$ \\
\hline $\begin{array}{l}\text { AFB1-diet+ } 0.5 \% \text { HSCAS } \\
+0.5 \% \mathrm{TP}\end{array}$ & $113.00^{\mathrm{cd}}$ & $472.66^{\mathrm{b}}$ & $21.16^{\mathrm{b}}$ & $280.33^{\mathrm{cd}}$ & $63.50^{\mathrm{c}}$ & $0.353^{\mathrm{b}}$ & $2.90^{\mathrm{b}}$ & $0.20^{\mathrm{b}}$ \\
\hline SEM & 1.193 & 5.149 & 0.831 & 2.515 & 1.240 & 0.021 & 0.052 & 0.056 \\
\hline p-value & 0.0001 & 0.0001 & 0.0001 & 0.0001 & 0.0001 & 0.0001 & 0.0001 & 0.0001 \\
\hline
\end{tabular}

${ }^{\mathrm{a}-\mathrm{c}}$ Means with different superscripts in a column differ significantly $(\mathrm{P}<0.05)$; AFB1 = aflatoxin B1; $\mathrm{TP}=$ turmeric powder; HSCAS = hydrated sodium calcium aluminosilicate.; SEM = Standard Error of the mean; SOD, total superoxide dismutase; GSH-Px, glutathione peroxidase; MDA, malondialdehyde; ND: not detected (determination limit of the analytical method: $0.01 \mathrm{ug} / \mathrm{kg}$ for aflatoxin B1)

Table (5): Haemagglutination Inhibition (HI) antibody titer against Newcastle disease vaccine of chicks fed diets containing HSCAS, TP and AFB1.

\begin{tabular}{|l|c|c|c|c|c|}
\hline \multirow{2}{*}{ Treatments } & \multicolumn{5}{|c|}{ HI titer/week } \\
\cline { 2 - 6 } & $\mathbf{1}^{\text {st }}$ & $\mathbf{2}^{\text {nd }}$ & $\mathbf{3}^{\text {rd }}$ & $\mathbf{4}^{\text {th }}$ & $\mathbf{5}^{\text {th }}$ \\
\hline Basal diet (Control) & & & & & \\
Control + 0.5\% TP & $5.00^{\mathrm{ab}}$ & $4.06^{\mathrm{a}}$ & $6.60^{\mathrm{ab}}$ & $5.60^{\mathrm{a}}$ & $6.03^{\mathrm{abc}}$ \\
Control + 0.5\% HSCAS & $5.33^{\mathrm{a}}$ & $4.33^{\mathrm{a}}$ & $6.80^{\mathrm{a}}$ & $5.80^{\mathrm{a}}$ & $6.23^{\mathrm{a}}$ \\
Control + 05\% TP + 0.5\% HSCAS & $5.33^{\mathrm{a}}$ & $4.33^{\mathrm{a}}$ & $6.73^{\mathrm{a}}$ & $5.70^{\mathrm{a}}$ & $6.16^{\mathrm{ab}}$ \\
Control +1ppm AFB1/kg diet & $5.66^{\mathrm{a}}$ & $4.13^{\mathrm{a}}$ & $6.90^{\mathrm{a}}$ & $5.66^{\mathrm{a}}$ & $6.20^{\mathrm{a}}$ \\
(AFB1-diet) & $2.33^{\mathrm{d}}$ & $1.96^{\mathrm{d}}$ & $4.56^{\mathrm{d}}$ & $3.53^{\mathrm{e}}$ & $3.66^{\mathrm{e}}$ \\
AFB1-diet +0.5\% TP & & & & \\
AFB1-diet + 0.5\% HSCAS & & & & \\
AFB1-diet + 0.5\%HSCAS + & $3.66^{\mathrm{c}}$ & $3.56^{\mathrm{b}}$ & $6.00^{\mathrm{c}}$ & $4.36^{\mathrm{c}}$ & $5.83^{\mathrm{bc}}$ \\
0.5\%TP & $4.00^{\mathrm{bc}}$ & $2.90^{\mathrm{c}}$ & $5.80^{\mathrm{c}}$ & $3.93^{\mathrm{d}}$ & $5.06^{\mathrm{d}}$ \\
SEM & $3.50^{\mathrm{b}}$ & $6.10^{\mathrm{bc}}$ & $4.80^{\mathrm{b}}$ & $5.80^{\mathrm{c}}$ \\
p-value & & & & & \\
& & & & & \\
\end{tabular}

${ }^{\mathrm{a}-\mathrm{C}}$ Means with different superscripts in a column differ significantly $(\mathrm{P}<0.05)$;SEM $=$ Standard Error of the mean; AFB1 = aflatoxin B1; TP $=$ turmeric powder; HSCAS $=$ hydrated sodium calcium aluminosilicate. 
Reda A. Hassan ${ }^{1}$ et al.

\section{REFERENCES}

Abdel-Wahhab, M.A. and Aly, S.E. 2005. Antioxidant property of Nigella sativa (black cumin) and Syzygiumaromaticum (clove) in rats during aflatoxicosis. $J$. Appl. Toxicol., 25: 218-223.

Abdel-Wahhab, M.A., Nada, S.A., Farag, I.M., Abbas, N.F. and Amra, H.A. 1998. Potential of protective effect of HSCAS and bentonite against dietary aflatoxicosis in rat: With special reference to chromosomalaberrations. Nat. Toxins. 6: 211-218.

AOAC. 2005. Association of Official Analytical Chemists of Official Methods of Analysis. 18th Edn., Washington, D.C..

Aravind, K.L., Patil, V.S., Davegowda, G., Umakantha, B. and Ganpule, S. P. 2003. Efficacy of esterified glucomannan to counteract mycotoxicosis in naturally contaminated feed on performance and serum biochemical and hematological parameters in broilers. Poultry Sci., 82: 571-576.

Bailey, C.A., Latimer, G.W., Barr, A.C., Wigle, W.L., Haq, A.U., Balthrop, J.E. and Kubena, L.F. 2006. Efficacy of montmorillonite clay (NovaSil PLUS) for protecting full-term broilers from aflatoxicosis. J. Appl. Poult. Kositcharoenkul Res., 15: 198-206.

Bintvihok, A. 2006. Effect of dietary calcium propionate on performance, hepatic enzyme activities and aflatoxin residues in broilers fed a diet containing low levels of aflatoxin B1. Toxicol., 47: 41-46.

Chun, K., Sohn, Y., Kim, H., Kim, O., Park, K., Lee, J., Moon, A., Lee, S. and Surh, Y. 1999. Antitumor promoting potential of naturally occurring diarylheptanoids structurally related to curcumin. Mutat. Res., 428: 49-57.
Denli, M., Okan, F., Doran, F. and Inal, T.C. 2005. Effect of dietary Conjugated Linoleic Acid (CLA) on carcass quality, serum lipid variables and histopathological changes of broiler chickens infected with aflatoxin B1. S. Afr. J. Anim. Sci., 35: 109-116.

Denli, M., Blandon, J.C., Guynot, M.E., Salado, S. and Perez, J.F. 2009. Effects of dietary AflaDetox on performance, serum biochemistry, histopathological changes and aflatoxin residues in broilers exposed to aflatoxin B1. Poultry Sci.,88: 1444-1451.

Duncan DB. Multiple range and multiple FTest, Biometrics 1955;11: 1-42.

Duncan, J.R. and Prasse, K.W. Veterinary Laboratory Medicine: Clinical Pathology. 2nd Edn., Iowa State University Press, Ames, IA. 1986.

Emadi, M. and Kermanshahi, H. 2007. Effect of turmeric rhizome powder on the activity of some blood enzymes in broiler chickens. Int. J. Poultry Sci., 6: 48-51.

Galvano, F., Piva, A., Ritieni, A. and Galvano, G. 2001. Dietary strategies to counteract the effects of mycotoxins: A review. J. Food Prot., 64: 120-131.

Gowda, N.K.S., Ledouxa, D.R., Rottinghausa, G.E., Bermudeza, A.J. and Chena, Y.C. 2008. Efficacy of turmeric (Curcuma longa), containing a known level of curcumin and a hydrated sodium calcium aluminosilicate to ameliorate the adverse effects of aflatoxinin broiler chicks. Poultry Sci., 87: 1125-1130.

Hasan, A.A., Shahid, R., Tassawar, H.S. 2000. Iqbal, A. Effect of sodium bentonite as aflatoxin binder in broiler feeds containing fungal infected grains. Pak. J. Agri. Sci., 37: 163-165.

Hsieh, DPH. Basic metabolic effects of mycotoxins interactions of mycotoxins in animal production. Proceeding of 
Aflatoxin B1, Broiler chicks, Detoxification, HSCAS, Turmeric.

Symposium, National Academy of Sciences. Washington, DC, pp: 43-55. 1979.

Ibrahim, I.K., Shareef, A.M. and AlJoubory, K.M.T. 2000. Ameliorative effects of sodium bentonite on phagocytosis and Newcastle disease antibody formation in broiler chickens during aflatoxicosis. Res. Vet. Sci., 69 : 119-122.

Imlay, J.A. and Linn, S. 1988. DNA damage and oxygen radical toxicity. Science 240:1302-1309.

Iqbal, M., Sharma, S.D., Okazaki, Y., Fujisawa, M. and Okada, S. 2003. Dietary supplementation of curcumin enhances antioxidant and phase-I metabolizing enzymes in ddY male mice: Possible role in protection against chemical carcinogenesis and toxicity. Pharmacol. Toxicol. 92:33-38.

Jayaprakasha, G.K., Rao, L.J.M. and Sakariah, K.K. 2002. Improved HPLC method for the determination of curcumin, demehoxycurcumin and bisdemethoxy curcumin. J Agric Food Chem. 50: 3668-3672.

Johri, T.S. and Majumdar, S. 199. Effect of methionine, choline, BHT, supplemented aflatoxic diets. Proceeding of 13th National Symposium Indian Poultry Science Assoc., Held at Bombay on Dec. 20-22. 1990.

Kalorey, D.R. Effect of aflatoxin on humoral immune system of chicks. Ph.D. Thesis, Krishi Vidyapeeth, Akola, India. 1993.

Kubena, L.F., Harvey, R.B., Phillips, T.D., Corrier, D.E. and Huff, W.E. 1990a. Diminution of aflatoxicosis by hydrated sodium calcium aluminosilicate. Poultry Sci., 69: 727-735.

Kubena, L.F., Harvey, R.B., Huff, W.E., Elissalde, M.H., Yersi, A.G., Phillips, T.D. and Rottinghaus, G.E.1993.
Efficacy of hydrated sodium calcium aluminosilicate to reduce the toxicity of aflatoxin and diacetoxyscirpenol. Poultry Sci., 72: 51-59.

Kurkure, N.V., Pawar, S.P., Kognole, S.M., Bhandarkar, A.G., Ganorkar, A.G. and Kalorey. D.R. 2000. Ameliorative effect of turmeric (Curcuma longa) in induced aflatoxicosis in cockrels. Ind. J. Vet. Pathol. 24:26-28.

Lee, S.E., Campbell, B.C., Molyneux, R..J, Hasegawa, S. and Lee, H.S. 2001. Inhibitory effects of naturally occurring compounds on aflatoxin B1 biotransformation. J. Agric. Food Chem., 49: 5171-5177.

Ledoux, D.R., Rottinghaus, G.E., Bermudez, A.J. and Alonso-Debolt, $M$. 1998. Efficacy of hydrated sodium calcium aluminosilicate to ameliorate the toxic effects of aflatoxin in broiler chicks. Poultry Sci., 77: 204-210.

Mabbett, T. 2005. Integrated management of mycotoxins. Poultry Int., 44: 10-14.

Manegar, G.A., Shambulingappa, B.E. and Ananda, K.J. 2010. Studies on tolerance limit of aflatoxin in commercial broilers. Libyan Agric. Res. Center J. Inter., 1: 177-181.

Miazzo, R.D., Peralta, M.F., Magnoli, C., Salvano, M., Ferrero, S., Chiacchiera, S.M., Carvalho, E.C.Q., Rosa, C.A.R. and Dalcero, A. 2005. Efficacy of sodium bentonite as a detoxifier of broiler feed contaminated with aflatoxin and fumonisin. Poultry Sci., 84: 1-8.

Mussaddeq, Y., Begum, I. and Akhter, S. 2000. Activity of aflatoxin adsorbents in poultry feed. Pak. J. Biol. Sci., 10: 16971699.

National Research Council. Nutrient Requirement of Poultry. 9th Revised ed. Washington: National Academy Press. 1994. 
Nelson, T.S., Johnson, Z., Kirby, L.K. and Beasly, J.N. 1982. Digestion of dry matter and amino acids and energy utilization by chicks fed mold corn containing mycotoxins. Poultry Sci., 61: 584-585.

Osborne, D.J. and Hamilton, P.B. 1981. Decreased pancreatic digestive enzymes during aflatoxicosis. Poultry Sci., 60: 1818-1821.

Pasha, T.N., Farooq, M.U., Khattak, F.M., Jabbar, M.A. and Khan, A.D. 2007. Effectiveness of sodium bentonite and two commercial products as aflatoxin absorbents in diets for broiler chickens. Anim. Feed Sci. Technol., 132: 103-110.

Rangsaz, N. and Ahangaran, M.G. 2011. Evaluation of turmeric extract on performance indices impressed by induced aflatoxicosis in broiler chickens. Toxicol. Ind. Hlth., 10: 956-960.

Rastogi, R.A., Srivastava, K. and Rastogi, A.K. 2001. Long term effect of aflatoxin B1 on lipid peroxidation in rat liver and kidney: Effect of Picroliv and Silymarin. Phytother. Res. 15:307-310.

Renzulli, C., Galvano, F., Pierdomenico, L., Speroni, E. and Guerra, M.C. 2004. Effects of rosamarinic acid against aflatoxin B1 and ochratoxinA induced cell damage in a human hepatoma cell line (Hep G2). J. Appl. Toxicol. 24:289296.

Rottinghaus, G.E., Olsen, B. and Osweiler, G.D. Rapid screening method for aflatoxin B1, zearalenone, ochratoxin A, T-2 toxin, diacetoxyscirpenol and vomitoxin. Proceeding of 25th Annual American Association of Veterinary Laboratory Diagnosticians, Nashville, TN, pp: 477-484. 1982.

Rauber, R.H., Dilkin, P., Giacomini, L.Z., Araujo de Almeida, C.A. and Mallmann, C.A. Performance of turkey poults fed different doses of aflatoxins in the diet. Poultry Sci., 86: 1620-1624.

Soni, K.B., Lahiri, M., Chackradeo, P., Bhid, S.V. and Kuttan, R. 1997. Protective effect of food additives on aflatoxin-induced mutagenicity and hepatocarcinogenicity. Cancer Lett., 115: 129-133.

Sarr, A.B., Clement, B.A. and Phillips, T.D. 1990. Effects of molecular structure on the chemisorption of aflatoxin B1 and related compounds by hydrated sodium calcium aluminosilicate. Toxicol., 10 : 163.

Sehu, A., Ergün, L., Cakir, S., Ergün, E., Canteki, Z., Sahin, T., Essiz, D., Sareyyüpoğlu, B., Gürel, Y. and Yiğit, Y. 2007. Hydrated sodium calcium aluminosilicate for reduction of aflatoxin in quails (Coturnixcoturnix japonica). Dtsch. Tierarztl. Wochenschr., 114: 252259.

Sharline, K.S.B., Howarth, B.J. and Wyatt, R.D. 1980. Effect of dietary aflatoxin on reproductive performance of mature white leghorn. Poultry Sci., 59: 1311-1315.

Shotwell, L.O., Hesseltine, C.W., Stubblefield, R.D. and Sorenson, W.G. 1966. Production of aflatoxin on rice. Appl Micrbiol 14:425-8.

Shi, Y.H., Xu, Z.R., Feng, J.L. and Wang, C.Z. 2006. Efficacy of modified montmorillonite nanocomposite to reduce the toxicity of aflatoxin in broiler chicks. Anim. Feed Sci. Technol., 129: 138-148.

Smith, J.E., Solomons, G., Lewis, C. and Anderson, J.G. 1995. Role of mycotoxins in human and animal nutrition and health. Nat. Toxins, 3: 187192.

Stove, S.D., Anguelov, G., Ivanov, I. and Pavlov, D. 2000. Influence of OA and an extract of artichoke on the vaccinal 
Aflatoxin B1, Broiler chicks, Detoxification, HSCAS, Turmeric.

immunity and health in broiler chicks. Exp. Toxicol. Pathol. 52:43-55.

Surai, P.F. Natural Antioxidants and Mycotoxins in Natural Antioxidants in Avian Nutrition and Reproduction. 1st Edn., Nottingham University Press, Nottingham, UK, pp: 455-509. 2002.

Tedesco, D., Steidler, S., Galletti, S., Taneni, M., Sonzogni, $O$. and Ravarotto, L. 2004. Efficacy of silymarin-phospholipid complex in reducing the toxicity of aflatoxin $\mathrm{B} 1$ in broiler chicks. Poultry Sci., 83: 18391843.

Tejada-Castaneda, Z.I., Vila-Gonzalez, E.A., Casaubon-Huguenin, M.T., Cervantes-Olivares, R.A., Va-Pelaez, C., Hernandez-Baumgarten, E.M. and Moreno-Martinez, E. 2008. Biodetoxification of aflatoxincontaminated chick feed. Poultry Sci., 87: 1569-1576.

Tessari, E.N., Oliveira, C.A., Cardoso, A.L., Ledoux, D.R. and Rottinghaus, G.E. 2006. Effects of aflatoxin $B 1$ and fumonisin B1 on body weight, antibody titres and histology of broiler chicks. $B r$. Poult. Sci., 47: 357-364.
Verma, J., Swain, B.K. and Johri, T.S. 2002. Effect of various levels of aflatoxin and ochratoxin $\mathrm{A}$ and combinations thereof on protein and energy utilization in broilers. J. Sci. Food Agric., 82: 14121417.

Yang, J., Bai, F., Zhang, K., Bai, S., Peng, X., Ding, X., Li, Y., Zhang, J. and Zhao, L. 2012. Effects of feeding corn naturally contaminated with aflatoxin B1 and B2 on hepatic functions of broilers. Poult. Sci. 91:2792-2801.

Yarru, L.P., Sttivari, R.S., Gowda, N.K.S., Antoniou, E., Ledoux, D.R. and Rottinghaus, G.E. 2009b. Effects of turmeric (Curcuma longa) on the expression of hepatic genes associated with biotransformation, antioxidant and immune systems in broiler chicks fed aflatoxin. Poultry Sci., 88: 2620-2627.

Zhao, J., Shirley, R.B., Dibner, J.D., Uraizee, F., Officer, M., Kitchell, M., Vazquez-Anon, M. and Knight, C.D. 2010. Comparison of hydrated sodium calcium aluminosilicate and yeast cell wall on counteracting aflatoxicosis in broiler chicks. Poultry Sci., 89: 21472156. 
Reda A. Hassan ${ }^{1}$ et al.

\title{
الملخص العربى
}

\section{مقارنة سليكات الصوديوم والكالسيوم والألومنيوم بالكركم لتقليل التأثيرات الضارة للأفلاتوكسين فى كتاكيت التسمين}

\author{
رضا على حسن' - يحى زكريا عيد ' - ابتهال عبد المنعم حسن '-خليل محمد عطية ' محمد حسنى عسر'

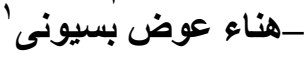

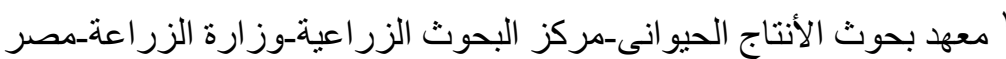

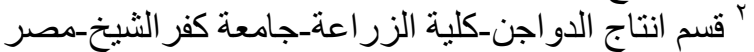

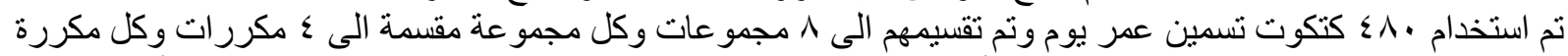

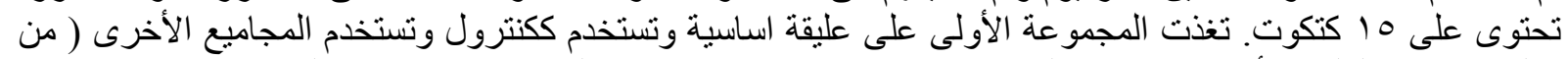

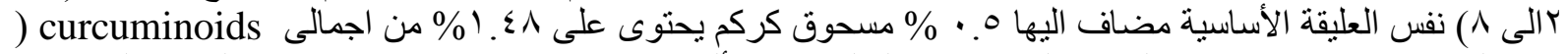

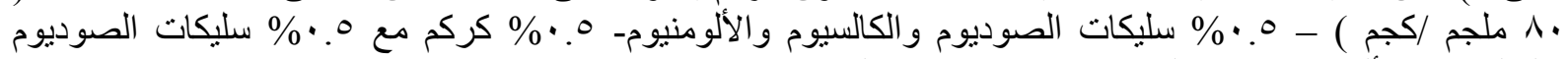

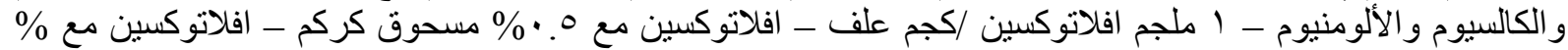

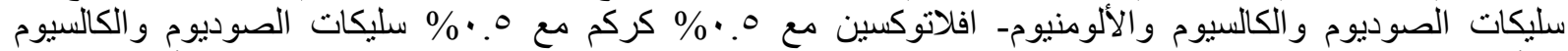

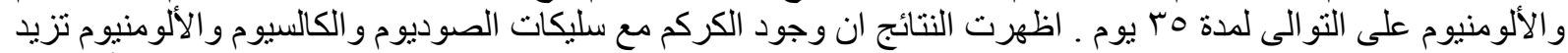

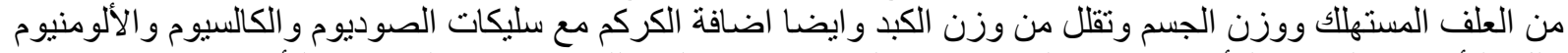

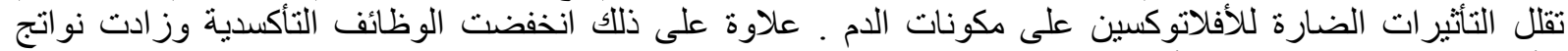

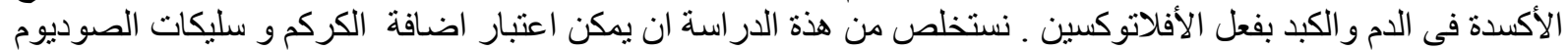
و الكالسيوم و الألومنيوم طريقة مركبة للسيطرة على الأفلانوكسين. 